\title{
The Latecomers' Early Colonial Experiment- The Uniqueness of the German Case
}

\begin{abstract}
By Nikolaos Mavropoulos*
Modern Germany (1871), Japan (1868) and Italy (1861) were formed in the same period, the period of the New Imperialism, a time of diplomatic mistrust, protectionism, frenetic colonial and economic rivalry and of militarism, when the Great Powers (British Empire, the French Third Republic and the Russian Empire) had already established their hegemonic position in the world. Germany, Japan and Italy at the end of the 19th century were in need of stability, internal and external security and immediate settlement of the economic and social problems arising from the rapid increase of their population. Furthermore, seeking to compete on an equal footing with the Powers of the era, claiming a "place in the sun", they considered modernization and rapid industrialization as the only way forward. Despite these apparent similarities however, the German case is distinct and unparalleled for a series of reasons.
\end{abstract}

\section{Literature Review}

International historiography has ignored the phenomenon for decades. Even in Italy, Germany or Japan over the last thirty years and until recently the countries' colonial history was a secondary and forgotten part of the national history. It seems that the Italian, German and Japanese governments and academic circles had no desire to allow or to engage into a systematic study of their colonial presence overseas, an event which would confront them with the mistakes of the past. The ignorance, the disregard for the foreign sources, the ambiguity and the lack of debate perpetuated the study of the events with blinkers on: the inconsistencies, the contradictions, the myths and the stereotypes about a "humanitarian" and "different" colonial administration.

\section{Introduction}

The indisputable similarity between Germany, Italy and Japan in the 19th century was the wide spread narrative of the "underprivileged latecomer" utilized by all three sides to justify their intention to upturn the international system's status quo. Historians had argued that Meiji Japan, Liberal Italy and Imperial Germany pursued a reactionary, authoritarian modernization that led eventually to totalitarianism. Even though this statement holds some validity for

*Max Weber Postdoctoral Fellow, Department of History and Civilization, European University Institute, Italy. 
the $20^{\text {th }}$ century, in the end of the 19th their potential, their aspirations and policies were diametrically different. Even if the political elites in these countries vigorously attempted to catch up with the rest of the world their actual differences were chaotic. Militarily and politically Germany was a superpower; economically it was highly industrialized and its banks and merchant class invested and active all over the world. On the other hand, Japan and Italy were feeble militarily, politically insignificant and economically backward.

\section{A Brief Comparison of Italy's and Germany's Initial Colonial Disposition}

For many scholars Rome's inclination towards expansionism overseas is reminiscent to the Berlin's late 19th century strive to also gain "a place under the sun". The fact that the two states were formed late in relation to the European powers, the anxiety to catch up with their colonial empires, the overpopulation problem, their conviction to achieve a prominent place in world politics, their later rejection of liberal and pacifist ideas after the first world war, their intertwined political evolution in the first half of the 20th century cannot be a coincidence ${ }^{1}$. Italian and German colonialisms share indubitably some common ground according to the historian Carlo Ghisalberti. According to him both cases arose by private initiatives, missionaries and explorers that gave publicity to the colonial matters among their contemporary compatriots. Moreover, both states, embracing the prevailing militaristic and chauvinistic concepts in the late 19th century, aspired imperial greatness; in this retrospect the inspiring, influential effect of Rome's imperial heritage was matched by Germany's world domination and hegemonic ambitions under Kaiser Wilhelm as a much-needed ideological legitimization of expansion ${ }^{2}$. Furthermore, upon the aftermath of the Italian and German states' formation, the ruling classes and the political leadership, crystallized on Bismarck's and Cavour's figures, appeared disinterested about colonial expansion, having to confront more urgent socio-economic problems. Italian and German governments never seriously undertook the project of establishing penitentiary colonies and finally, both states happened to release their dominions abruptly after military defeat (officially in 1919 for Germany, 1947 for Italy), avoiding the decolonization perplex and traumatic period,

1. These treats are also valid for Meiji Japan (post 1868) as well. For Andrea Boltho Japan's, Germany's and Italy's economic development is strikingly similar. Their rapid reconstruction and subsequent economic miracle after the end of the Second World War attests to this view, see Andrea Boltho, "Italy and the World Economy, 1861-2011," in 2011 Italy, Germany, Japan: From Economic Miracles to Virtual Stagnation, International conference (Rome, 12-15 October 2011), 4-5.

2. Carlo Ghisalberti, "Due colonialismi a confronto: Italia e Germania nella loro espansione oltremare sino alla prima guerra mondiale," Clio Rivista Trimestrale di Studi Storici, 33, no.2 (1997): 329-333. 
experienced by other ex-colonial states, a fact that gave the latter the opportunity to acknowledge and reconcile with their oppressing past ${ }^{3}$. For the German Historian Holger Afflerbach, besides the obvious common grounds of overpopulation and the anxiety of being excluded by a British-French dominated setting, early Germany and early Italy demonstrated the same reliance in military means in Africa. In other words, the military was the main factor behind the pursuit of colonial acquisitions and the means of their subsequent administration. However, he observed that the capacity and prestige that the German forces enjoyed in Africa was superior to the Italian, particularly in the aftermath of the Adwa battle ${ }^{5}$.

\section{The Nature of Berlin's Early Oversees Expansion}

The author's view is that is imperative to re-enact the basic steps of the early German colonialism in order to inquire into its nature and eventually draw some more accurate conclusions in regards to its similarity with the Italian case. The fact that in the late 1890 Imperial Germany launched an aggressive world policy is well known. Political, economic and military predominance led the Wilhelmine period's ruling classes to pursue a European and global superpower status ${ }^{6}$. Before the consolidation of its overwhelming power, how did Germany handled the first challenges concerning the heated and trendy colonial debate? Summarizing initially Bismarckian's era colonial policy, and outlining the leading expansionist ideologies is essential to shed some light on the early German colonial policy. For this reason we will briefly demonstrate the way that Berlin operated in Africa during the acquisition of its first colony, Namimbia, in contrast to the acquisition of Italian Eritrea and Japanese Taiwan.

Typically enough the missionaries were the first to embark in African "moralistic" adventures laying the groundwork for the future German colonial edifice ${ }^{7}$. In particular the Rhenish missionaries have been an effective and willing instrument of the German government, signing protection treaties, acting as

3. Ibid., 335-340.

4. Holger Afflerbach, "«Duo quum faciunt idem...» Militärische Aspekte der deutschen und italienischen Kolonialgeschichte vor dem Ersten Weltkrieg," in Annali dell' Istituto Storico Italo-Germanico (Trento, 1998), 24, 116-117, 130-131.

5. Ibid., 137-139.

6. Roger Fletcher, "Revisionism and Wilhelmine Imperialism", Journal of Contemporary History, 23, no. 3 (1988): 349-350.

7. Ulrich van der Heyden, "Christian Missionary Societies in the German Colonies, 1884/85-1914/15", in German Colonialism, Race, the Holocaust, and Postwar Germany, ed. V. Langbehn, M. Salama (New York, 2011), 216-217. 
advisors and translators in Africa ${ }^{8}$. However, their propaganda would never have stimulated the government's attention if it were not for the financial and industrial cycles' interests. In the 1870-1880s many of the exploration and scientific missions abroad were subsidized by the Deutsche Bank and the Diskontogesellschaft bank, the latter's chairman Adolph von Hansemann (1826-1903) participating actively in the affirmation of German interests in Samoa in 1880. Explorers Heinrich Barth (1821-1865), Johann Rebmann (1820-1876), Johann Ludwig Krapf (1810-1881), Hermann von Wissmann (1853-1905), Georg August Schweinfurth (1836-1925) and Friedrich Gerhard Rohlfs (1831-1896) penetrated and explored the African interior in the mid-late $19^{\text {th }}$ century ${ }^{9}$.

Bismarck until the 1870s was averse to any kind of shady, precarious undertaking that could destabilize Berlin's preponderance in Europe. He did not desire to incite international complications and also believed that the connection between colonies and commerce was illusive. His famous statement on 5 December 1888 that his "map of Africa was in Europe", meant that his priority was the prevention of a hostile coalition to Germany's hegemonial status in Europe by diverting tensions in the colonial periphery ${ }^{10}$. In the 1870-1880s heavy industrialization and capitalism meant the existence of a growing socialist movement in the Reichstag. Bismarck tried to tame it by violence and favourable law reformations such as the 1881 and 1883 social insurance measures. As for Africa Bismarck finally decided to reluctantly back the expansionists' undertakings in order to appease them but left the initiative to the experienced still adventurist entrepreneurs. In 1882 the German Colonial League was founded. The association took on the task of advertising the economic, political and even religious possibilities of colonial expansion to the German bourgeoisie. Among its founders were aristocrats, merchants, royals, bankers and representatives of the shipbuilding, arms and liquor industrial cycles. During the 1882-1885 economic depression in Europe, the national-liberal deputy Hammacher (Friedrich Adolf Hammacher 1824-1904) was claiming in the parliament: "The surplus production crisis could be surpassed by the opening of new trade outlets". Colonial propaganda, influencing the public opinion, stepped in to highlight the obvious solution: colonization could resolve the social and financial strains deriving from the crisis. Amid this climate, in summer 1883, the merchant Adolf Lüderitz (Franz Adolf Eduard Lüderitz 1834-1886), for a meagre compensation acquired from the local chieftains 900 square kilometres in Angra Pequenha, modern day Namibia. Soon after he stipulated a convention with some prominent

8. Nils Ole Oermann, Mission, Church and State Relations in South West Africa under German Rule (1884-1915), (Stuttgart, 1999), 54-55.

9. William Otto Henderson, The German colonial empire (London, 1993), 17-20.

10. Wolfgang J. Mommsen, "Bismarck, the Concert of Europe, and the Future of West Africa, 1883-1885", in Bismarck, Europe and Africa. The Berlin Conference 1884-1885 and the onset of Partition (ed. Stig Forster, Wolfgang J. Mommsen and Ronald Robinson), (New York, 1988), 152-153. 
bankers and industrialists, merely expecting Berlin's official approval. Bismarck, who in February 1883 appeared confident that his government will stay away from "any colonial intrigue", in November 1883 addressed an official inquiry to London, with the view to clarify if Lüderitz's territory made part of the British colony's of the Cape sphere of influence. When the response came back positive, the Chancellor asked on what grounds the British based their argument; the lack of reply infuriated Bismarck, who took the situation in his own hands ${ }^{11}$.

Bismarck having established a mutual understanding with the French president Ferry, in Madagascar, Tonkin, Tunisia, as already explained, opted for the isolation of London. The Triple alliance, the Russian-British antagonism in Afghanistan and the precarious British position in Egypt gave a clear advantage to the German side. On 24 April 1884 Berlin declared that the German citizens and their properties in Namibia were from then on under the state's protection. The British authorities of the Cape posed obstacles to the German penetration as they were already doing in the Fiji Islands, where German firms had acquired sugar plantations in 1885 . The German society for the commerce and the sugar plantations, created by industrialists, would be firmly safeguarded by Bismarck against London's arrogance and avarice. Its ambassador in Berlin, during a meeting with the chancellor was scolded and threatened that if his government continues to ignore the German legitimate rights in New Guinea, he would leave it vulnerable against the other powers in Egypt. Lord Derby, secretary of State for the colonies, asserted in May 1884 that Britain would not allow any foreign installation north of the Cape. German newspapers attacked verbally the greedy British policy and called for the defence of the "honour of the nation" inciting popular chauvinism, a fact that Bismarck turned to his favour.

Upon the Chancellor's orders Gustav Nachtigal, now Tunis' consul, acting as an imperial commissioner, reached Cameroon, Togo and any other region in which German financial interests, especially the shipbuilding-trade company's Woermann, were active and raised the national flag, defying London. Berlin's agents acting resolutely expanded the boundaries of Lüderitz's German South West Africa and founded the colonies of Togoland and Cameroon in July 1884, amidst the exaltation of the bourgeoisie press. Exponents of militarism and social Darwinism operated promptly in South America and Africa to consolidate a chunk of the colonial cake before it was too late. London to hammer the menacing German penetration also in Tanganyika, present day Tanzania, and to settle the Congo's river basin control issue, aligned itself to Portugal, one of the principal contestants. Apropos, the 1884-1885 Berlin Conference was summoned, during which British agents under the pressure of the French-German-Belgian coalition annulled the agreement with Lisbon and recognised Belgium's pretensions in the area, among other issues. The very next day of the conference's closing date, on 26

11. Arkadij Erusalimskij Samsonovic, Bismarck: Diplomazia e Militarismo (Rome, 1969), 225-229. 
February 1885, Kaiser Wilhelm I (Wilhelm Friedrich Ludwig, 1797-1888) gave a free hand to Tanganyika's colonization endeavour. A heated rivalry erupted in East Africa amidst the press's battle cries, between the Germans and the British agents for the predominance upon the Zanzibari Sultan's mainland possessions. The Germans, who sent war ships in those waters, proved more successful in patronizing or intimidating the Sultan. Bismarck, authorised his son the foreign secretary to negotiate an agreement concerning East Africa with London, that welcomed the initiative amidst its Central Asian clashes with Saint-Petersburg. The partition and delimitation of the two spheres of influence was agreed on 29 October 1886 and 1 July 1890, known as the Heligoland-Zanzibar treaty. The middle and upper class called for expansion and primacy ideological schemes and the chancellor delivered. Petty bourgeoisie always susceptible to nationalistic demagogy and illusions of splendour backed Bismarck on the 28 October 1884 elections ${ }^{12}$. Historian Hans-Ulrich Wehler identified Bismarck's late bid for colonies as "social imperialism" since its main aim was to "preserve the supremacy of the traditional ruling elites and the authoritarian power structure within the socalled Kaiserreich"13.

Between the middle of the 19th century and the early 20th two perceptions dominated the German colonial ideology. The "emigrationist" theory dictated the establishment of settlement-farming colonies as the answer to the vast overpopulation problem and the subsequent social issues that derived from it, which led to the massive 19th century emigration flow. That way the cultural and economic loss to Germany would transform in oversees societies whose way of life, culture and economic contribution with the motherland would be protected by the German government ${ }^{14}$. The German population rose from 41 million in 1871 to 50 million in 1890 . In the three years $1880-1882$ half a million people immigrated to the Americas ${ }^{15}$. The emigrationist colonial advocates set their sights in South America and specifically in Argentina as the most suitable host. Moreover, German commercial influence (informal imperialism) had penetrated the region in a number of ways: capital investments, military presence, establishment of shipping lines, banks, factories ${ }^{16}$. Despite the fact, when the German Empire was founded the most promising territories for white settlement were already occupied, bankers such as Hansemann, traders such as Woermann, authors Friedrich Fabri (1824-1891) and Heinrich Gotthard von Treitschke (1834 1896) supported firmly the colonial idea. The latter told his students: "Today we

12. Ibid., 235-247

13. John Lowe, The Great Powers and the German Problem (1865-1925) (London, 1994), 78.

14. Woodruff D. Smith, "The Ideology of German Colonialism, 1840-1906", The Journal of Modern History, 46, no. 4 (1974): 641-643.

15. William Otto Henderson, Studies in German colonial history (London, 1962), 44.

16 Ian L. D. Forbes, "Social Imperialism and Wilhelmine Germany," The Historical Journal, 22, no.2 (1979), 334-335. 
see the nations of Europe busily engaged in creating all over the globe a wholesale aristocracy of the white race. That nation which does not take a share in this great rivalry will play a pitiful part at some day later. It is therefore a vital question for a great nation today to display a craving for colonies"17.

In contrast the economic theory viewed colonies as supplements of Germany's industrial and commercial development. Instead of large-scale settlements, importation of raw materials, agricultural goods and new trade opportunities were envisioned ${ }^{18}$. Amidst the imperialistic struggle the influential economist Georg Friedrich List (1789-1846) proposed the expansion of German industrial potency in a way to check British or other commercial and political control of the mid-19th century world. Eventual economic depressions or overproduction problems would be resolved by an "export offensive" both overseas and in Europe; a relentless, omnipresent economic penetration under the aegis of central interventism and protection against disruptive internal (liberal) social forces or foreign competition was achieved before the turn of the century.

Bismarck, in 1882-1883, now a nominal supporter of the economic-colonial concept understood the popularity of the emigrationist one and allegedly adopted it for electioneering purposes. Accordingly, and ever cunningly exploited both tendencies to impose its authoritarian policies and suppress the left-liberal opposition in the parliament. ${ }^{19}$ As some scholars maintain, the domestic policy and not the economic factor was German colonialism's driving force. Furthermore, the industrialists and capitalists took advantage of the popular agitation concerning the overpopulation's immigration to fertile, suitable settlement-agricultural colonies. Disinterested about the production of agricultural foodstuffs in south America diverted the focus to the tropical colonies, as reservoirs of raw materials such as rubber for their ever-expanding industries. In the same manner the shipping companies exploited the phenomenon of "navalism" to secure government subsidies. It is true that a Hamburg Chamber of Commerce petition on 6 July 1883 requested the occupation of a West Africa anchorage. Nevertheless, for some scholars commercial interests can be seen as a complimentary to internal demand for expansion or ruling classes' resolution to maintain "social order" factor ${ }^{20}$.

17. Henderson, Colonial Empire, 27.

18. The chancellor's expectations that colonies could be administered informally, by British type chartered associations, were soon disappointed and resort to Reichstag's contribution was unavoidable. Togo, Cameroon, Kiaochow and the Pacific colonies were acquired and administered as "economic" colonies whereas Southwest Africa was meant to as an agricultural settlement, see Smith, "The Ideology of German Colonialism," 657658.

19. Ibid., 649-653.

20. Arne Perras, Carl Peters and German Imperialism 1856-1918 A Political Biography (New York, 2004), 41-46. 
Others asserted that the economic-industrial component was the most prevalent among others in shaping a pre-colonial atmosphere and an inclination towards commercial and secondly political expansion. German trade volume had been roughly doubling every fifteen years, from 1840s to 1910s and the country had progressively become a leading player on the stage of international trade. The other influential factors were: the immigration problem, the existence of pressure groups-lobbies, the rising colonial propaganda, the growth of missionary mission and of geographical exploration societies outside Europe and in need of government's protection ${ }^{21}$. Ideologically, the proponents of German expansion rarely brought up the justifying schemes regarding the civilization mission upon the unfortunates of the third world, so beloved by the French, British and Italian colonialists. Instead they were prone to enact concepts of work ethics to the colonized and rational exploitation of the natural resources, securing the maximum profitability. When came to colonies business was priority and civilization should wait. For example, for Paris economic activities were not an end in themselves; rather they were part of the civilizing process. Apart this point, the German phenomenon seems to share a certain similarity with the French and not its Italian counterpart. Ruthless oppression, violence, and subjection were similarly employed by both Berlin and Paris in Africa. The French, convinced about their racial superiority and having wed their democratic revolutionary tradition with imperialism aimed to assimilate the local population after its subjection. Berlin, equally militaristic, used violent means in order to rule and extract profits, not concerning itself with the formulation of sweet-sounding theories and pretexts. Bismarck seeking efficiency and profitability gave priority to the business and not to the bureaucratic side of colonial politics ${ }^{22}$. His model was the British informal empire, that was self-administrated, inexpensive to the state's budget. The explorer Carl Peters once wrote: "all colonial establishments are in essence a business for the states". Theodor Gotthilf Leutwein (1849 -1921), Southwest Africa's governor from 1894 to 1904, conformingly stated: "The main purpose of all colonization is, if one leaves all made-up idealism and humanitarianism aside, a business. The colonizing race does not want to bring happiness to the indigenous population but looks after its own advantage and profit. So therefore, there is only one guideline for colonization and that is the pursuit of profitable business". Those interested in making Germany a colonial power, bestowed to the pursuit of business the outmost importance ${ }^{23}$.

21. Hatmut Pogge von Strandmann, "The Purpose of German Colonialism, or the Long Shadow of Bismarck's Colonial Policy", in German Colonialism, Race, the Holocaust, and Postwar Germany, ed. V. Langbehn, M. Salama (New York, 2011), 195-198.

22. The exploitation of South West Africa and Cameroun in particular were entrusted to concessionary companies right from the start see Robert Converin, "The Germans in Africa before 1918", in Colonialism in Africa, 1870-1960, ed. L. H. Gann, P. Duignan, vol. 1, The History and Politics of Colonialism, 1870-1914 (London, 1969), 387, 401-405.

23. Ibid., 195-209. 
The worldwide financial crisis of 1873-1896 (Great Depression) convinced Germany's trade and industrial elites that an "export offensive" was more than necessary for the wellbeing of the nation but more importantly of their firms. Moreover economists, merchants, bankers and industrialists all agreed that the greater the territory ruled by a state the most substantial the economic and political benefits. Regular invocation for protective tariffs, government intervention and the drive to secure colonies as available markets must be seen under this light. It was this very actively strenuous and antagonistic business environment that brought in the technical innovations, industrial reorganization (conglomeration) and aggressive investment and economic expansion policies that rendered Germany the word's major economic power, overthrowing the British at the end of the century ${ }^{24}$. Even before territorial acquisition in Africa and the Pacific it was mere capitalism and internal political factors that shaped German colonialism ${ }^{25}$. Hamburg's $\mathrm{s}^{26}$ trade houses, profiting from the 1855 commercial treaty with Zanzibar have been extremely active and profitable to that crucial centre of international commerce. Establishing trading connections with Arabs and Indian merchants were competing successfully with their British counterparts in the coast of east Africa. The principal commercial actor there has been William Henry O'Swald's (1832-1923) company since the 1850's; in 1869 the firm ventured successfully in Madagascar. In the same time the famous Woermann trade firm engaged in trading activities in Liberia and up to the 1860's dominated the Gabon-Cameroon trade. In the West African coast, the Jantzen and Thormahlen, Broehm and Wolber enterprises have been engaged to a lucrative transaction with the local tribes. The Bremen house of Vietor Sons and others established themselves in modern day Togo in the 1880's whereas the Goedelt firm penetrated the Dahomey market. Between 1876 and 1879 trading rights were secured by treaties in the south pacific islands. The principal commercial company Godeffroy, established in the region as early as 1857, profitable as may be there faced bankruptcy in 1879 due to unsuccessful speculation in Europe. A new German firm backed by the bankers Hansemann and Bleichroder intervened and kept Godeffroy's activities and property from falling into British hands demonstrating the ruling elites' chauvinistic sentiment but also a private capital capability for investments ${ }^{27}$.

24. Woodruff D. Smith, German Colonial Empire (Ann Arbor, 1998), 13-17.

25. George Steinmetz, The devil's handwriting. Precoloniality and the German colonial state in Qingdao, Samoa and Southwest Africa (Chicago 2007), 23.

26. In 1866 Hamburg alone maintained a network of 279 consular outposts around the world. The commercial treaties stipulated and the financial activities prepared the ground for the later colonial undertaking. See Sebastian Conrad, German colonialism, a short history (Cambridge, 2012), 25.

27. Henderson, Colonial Empire, 26-27. 


\section{The Uniqueness of Germany's Early Colonialism in Comparison to the Italian and Japanese Cases}

This brief outline is enough to help us trace the colossal gasp between the early Italian, early Japanese and Early German colonialisms, three cases that some could argue sprang out from identical ideological frameworks. These states were nurtured in the same 19th century bigoted, militaristic, atavistic, pro-expansionist framework were equally tormented by the population surpass question. Another interesting analogy was the ruling dynasties' inclination towards colonialism and some of their representatives' enthusiastic participation to the endeavour. Beyond these points we notice only striking inconsistencies. The most apparent certainly is the difference of their economic, commercial and mainly industrial capabilities. As far as Germany is concerned the economic explanation of imperialism makes sense. By the 1890's was an "economic giant with the world's most advanced technology and with a more efficient business structure and a higher investment rate than Britain"28. Germany had already reached the highest level of capitalism (monopoly capitalism), that justified every economic theory of imperialist expansion. The eventuality of exclusion of the world's markets in a state so interconnected and relying in trade was an actual menace whereas the Italian or Japanese call for raw materials was more elusive than real, a mere justification attempt. Germany actually needed rubber, chemicals, lumber for its industries and markets to export its surplus capital and its manufactured products. German entrepreneurs clashed with their French and British counterparts all over the globe in the race for concessions and privileges and demonstrated a mature capitalistic disposition for investments. When Berlin could not contribute to high risk enterprises or support its colonies' infrastructural development, there were bankers and components of the politico-commerce-industrial complex to step in. As Bismarck wished to involve the government as little as possible economically and administratively in Africa these businessmen invested not heavily but in a consistent way never conceivable in Rome or Tōkyō. In Italy and Japan, as we have seen, the industrial and foodstuff production could not cope with the counties' demands. Indeed, Italy was importing capitals from France and Germany, manufactured and agricultural goods whereas its anaemic economy and the meagre exports weighted upon the state budget. Furthermore, German expansionism was directed where business opportunities arose and established itself in regions that presented some kind of future profitability even if some dominions needed cash influxes from Berlin. In the contrary, the Italian counterpart was directed by others in any available or suggested region, ending up controlling Eritrea and Somalia, maybe the most destitute territories in Africa after failing to acquire more vital regions. Japan, on the other hand after a series of humiliations managed to acquire only Taiwan by 1895 an unhealthy, riotous

28. Smith, German Colonial Empire (Ann Arbor, 1998), 119. 
undesired island in the Far East. No one claims that Namibia and Tanganyika were abundant and rich worldly paradises; financially the majority of the German colonies relied in government support and, despite the investments, have not been particularly profitable ${ }^{29}$. Nor could someone argue that Berlin invested heavily in its colonies; none of the colonial powers did (the bulk of the British investments were not in its colonies but in America). Yet, they have been chosen by Germans, to satisfy German interests, produce profits for Germany based on sound capitalistic-profit making reasoning and contest in equal terms the British and French imperial monopoly. Berlin did not content itself with the colonial leftovers.

As shown the origins of newborn Germany's colonial disposition was very much analogous to the Italian and Japanese ones. The mid-19th century anxiety to catch up with the other powers, the overpopulation pressure, the ideological schemes, the travellers', pro-colonial "geographical" societies' groundwork in Africa and Asia were very much alike. Italy and Japan in this spectre cannot even claim a historical primacy in exploration-expansion or a unique naval tradition as a point of differentiation; the German based Hanseatic League monopolized Baltic Sea's commercial routes from the 14th to the 17th centuries. It is widely unknown but German explorers and sailors participated as crews in Portuguese discovery and trading expeditions around the globe as early as 1480 . Three German ships accompanied a Portuguese convoy in India in 1505 and two Germans sailed with Magellan (Ferdinand Magellan 1480-1521) in his trip around the world. In 1528 some German bankers and merchants were allowed by the Spanish authorities to establish trading posts in Venezuela. In modern day Ghana in 1863 the Elector of Brandenburg and Duke of Prussia Friedrich Wilhelm (16201688) established the first German colony, Gross Friedrichsburg. Earlier, in March 1862 the Brandenburg Africa company was established with a founding capital of 48.000 thalers and authorised to trade in the Guinea coast. In November 1865 the Elector acquired from the Danes the island of St Thomas in the Caribbean for 30 years. The commercial triangle between Europe, Africa and the Americas was curved and the Brandenburgian ships could finally embark on the lucrative slave trade. Therefore, this brief presentation attests to the fact that Italy and Japan were not distinguished by the others in terms of a distinct colonial tradition to legitimize its late 19th century's expansionist endeavours. The myth of the predestined, chosen, recently united, energetic nation espoused by the proimperialistic ruling elites apparently did apply to all of the three cases.

This brings us to our next point. Germany after defeating Denmark (1864), Austria (1866) and France (1871) was vested in the prestigious aura of the 19th century rising world power. Energetic and vigorous, after centuries of internal division, launched itself forward. Already dominant in Europe, envisioned for

29. L. H. Gann and Peter Duignan, The rulers of German Africa, 1884-1914 (Stanford, 1997), 56. 
itself the role of a global superpower (weltpolitik) namely after 1891. Militarily superior, politically stable thanks to Bismarck's machinations, industrially thriving soon threatened to overthrow all the other protagonists. Equally important was the consciousness of this power. Imperial Germany even before the Wilhelmine era, still without a formidable fleet, not only spoke on equal terms, in the aftermath of its foundation with the long-standing empires but defied and even menaced and provoked the fear of its interlocutors. The initial concerns about the creation of a rival coalition to supposedly liquidate the newly founded empire were discarded by Bismarck's brilliant divide and rule policy and were rebuffed until the First World War. Despite Germany's aggressive tactics and vulnerable strategic position, the country did not engage in any offensive or defensive European campaigns up to 1914. When it comes to Japan and Italy, we already investigated their inability to carve an autonomous, self interested foreign policy as a part of the $19^{\text {th }}$ international community. Optimism, enthusiasm and the sense of a unique mission for the future were evident after the two states' unification processes, achieved with great sacrifices, national heave and against all odds. Rome, however, had to be attached to the wagon of a greater power for its national security, conceal its real weakness under the shroud of militarism and expansion and affirm itself internationally. In the same way Tōkyō had to confer with the foreign diplomats and gain their approval every time it ventured abroad; its military feebleness, economic dependence and western racism placed the country at an inferior position to any white nation, even the second-rate Italy. However, imperial Germany was at the same time a potent if not the most potent state in the late 19th century. The Italian ruling classes were terrified by a possible French or Austro-Hungarian military intervention in the Pope's favour, considerable adversary for the newborn state. In need of reorganization and modernization, the military forces, having suffered tremendous debacles, such as in Lissa (1866), did not inspire confidence domestically and internationally. Similarly, Japan during the first decades of its unification and probably until the early $20^{\text {th }}$ century was preoccupied with the possibility of a Russian invasion. The appalling display of the nation's newly unified army during the Satsuma rebellion (1877) was a source of anxiety. Besides the facts, the psychological impact has to be taken into consideration. German merchants, politicians, servicemen felt robust and acted decisively, taking what they thought was rightfully theirs. Their Italian and Japanese counterparts, afraid not to displease even the weakest foreign governments, indecisive, at least, in regards to their colonial policy, sought the collaboration of the great powers often in a demining extent; the Italians were considered subordinates or British agents in Africa and the Japanese in several occasions annulled or postponed their colonial projects in the fear of western reaction. To the author's view when we are dealing with actions and decisions of individuals or groups of people the state of mind, disposition and mentality are crucial. Italy and Japan, insecure, ignored, 
secondary wished to make their voice heard whereas a dynamic Germany dictated the rules of the international race.

\section{Similarities and Differences between $19^{\text {th }}$ Century German and Japan}

Many scholars compare the 19th century Japanese case with the British or German one. Britain even though also an island state was technologically developed, robust, having the most powerful fleet and the most extensive empire in the world. The German Empire although it too was formed late (1871) and bedeviled like Japan by the problem of overpopulation did not share the same concerns about securing its independence as it was the superpower of the era, industrialized and militarily all-powerful the very next day after its unification. The indisputable similarity between the two states in the $19^{\text {th }}$ century was the wide spread scheme of the "underprivileged latecomer" utilized by the states to justify their intention to capsize the international system's status quo.

In the end of the 1870s Germany, military powerful and at the forefront of global trade and industry, appeared attractive to Meiji leaders. Excessive modernisation met conservative reactions. By the 1880s German patterns appeared more adaptable to the Japanese case and German political theory in line with Japanese conservative, nationalistic attitudes as opposed to those, like the Finance Minister Ōkuma Shigenobu, who were advocates of the British-American liberal thought ${ }^{30}$ and of a British style constitution. ${ }^{31}$ It was not only the educational system or the medical research that was adopted from the prestigious German model but a series of reforms, institutions and ideas all employed in the process of building and modernising the nation. ${ }^{32}$ Their implementation was

30. In the 1870s the ideas of liberalism, social rights and representative government were well spread thanks to the popular work of the British philosopher Herbert Spencer. See John D. Pierson, "The Early Liberal Thought of Tokutomi Sohō. Some Problems of Western Social Theory in Meiji Japan" in Monumenta Nipponica, Vol. 29, No. 2 (Summer, 1974), 199-201, 199-224. Spencer is considered the founder of the Social Darwinism theory, which influenced greatly the Japanese intelligentsia and ruling classes alike. Accelerated economic development would allow Japan to eventually obtain its place among the "civilized" nations. See Sherrie Cross, "Prestige and Comfort: The development of Social Darwinism in early Meiji Japan, and the role of Edward Sylvester Morse" in Annals of Science, . 53, no4: 330-332.

31. Rolf-Harald Wippich, "Infected with German Measles: Meiji Japan Under German Cultural Influence" in History of European Ideas, 20, no. 1-3 (1995): 339-402.

32. For others Japan had more in common with 19th century Tsarist Russia: reliance on western technology, employment of foreign advisors, adoption of German and Austrian models and the late 19th century modernization reforms were identical elements in both cases. See Cyril Black, The Modernization of Japan and Russia: A Comparative Study (Perspectives on modernization) (New York 1975), 126-135. 
applicable due to the "affinity of the philosophical basis" of Japan's and imperial Germany's political systems and their "ethno-centric nationalism" according to the historian Bernd Martin. Indeed, the national ideology on which post 1871 Germany was founded on was Christian religion and long standing feudalagrarian folkloric elements that served as the common origin and culture. As for the education, in the new born German Empire it was revolved around the exaltation of German nationality, moral discipline, obedience to one's superiors and Christian ethics. Indoctrination to patriotic and military duty was analogous to the Japanese practices. ${ }^{33}$ German studies, a growing orientation towards German patterns in law, economic and social policy, were promoted in the early 1880s as a conservative response to the Liberal Party and as a legal basis for revising the foreign treaties. ${ }^{34}$ German legal and constitutional models appeared to be more suitable and in line with the Japanese norms of sovereign power and the role of the emperor. ${ }^{35} \mathrm{~A}$ centralized, statist type of governance, the existence of noble elites with bureaucratic functions, the preponderant role of the military and the patriotic-nationalistic ideals that seemed to shape the relationship between the people and its leaders were up to a certain degree commonly shared by the two societies. ${ }^{36}$ The modern German state, constructed around the figure of the monarch, was established through "iron and blood" not vote and parliaments just as the Japanese state was in $1868 .{ }^{37}$ Nevertheless by the end of the 19th century,

33. Wippich, "Infected with German Measles", 83-85.

34. The advocate of modernization with less westernization, statesman Inoue Kowashi (1844-1895) favoured the more stable and similar "with regard to the circumstances of its unification" Prussian state model over the French, which had produced three revolutions between 1830 and 1871 and the American one that had led to the Civil War (1861-1865). In 1881 he suggested that if the government desired to make the Japanese more conservative-minded it should encourage the study of the German language. See Sukehiro Hirakawa, Japan's Love-Hate Relationship with the West (Folkestone 2005), 121-122.

35. Legal thinking of jurists such as Heinrich Rudolf Hermann Friedrich von Gneist (1816-1895) and sociologists like Lorenz von Stein (1815-1890), whom Itō Hirobumi met in his 1882-1883 visit while searching for suggestions for the future Japanese constitution, were transplanted in law schools, universities and legislative committees by the advisor Carl Friedrich Hermann Roesler (1834-1894). The model to be followed was the Prussian bureaucratic state, which had successfully reformed its economic, social and military institutions in the first half of the 19th century without representative institutions. See Erik Grimmer-Solem, "German Social Science, Meiji Conservatism, and the Peculiarities of Japanese History" in Journal of World History, Vol. 16, No. 2 (2005), 197-202, 187-222.

36. Franco Mazzei, "La Risposta Del Giappone Alla Sfida Modernizzante dell' Occidente" in 1868 Italia-Giappone: Intrecci Culturali, ed. Rosa Caroli (Venice 2008), 121.

37. Bernd Martin, Japan and Germany in the Modern World (Oxford, 1995), 17-35. 
besides these apparent similarities the two states had nothing else in common. ${ }^{38}$ The chaotic difference between Germany's industrial and military supremacy as a global superpower and an Asian, agrarian island state in the margin of the modernised world shaped their respective relations and attitudes concerning their foreign policy. Japanese economy was far less industrialized than Germany's and its trade largely controlled by foreign merchants enjoying treaty privileges.

\section{Conclusion}

It has to be stressed that early Italy and Japan were relegated to secondary international actors whereas Germany was the rising world power of the 19th and early 20th centuries. The fact that all three were formed late, willing to capsize the established unfair state of affairs in world politics and suffered from overpopulation are certainly important but not fundamental for the understanding of their foreign policies and territorial aspirations. Italian and Japanese strategic insecurity, the anxiety and psychological pressure stemming from this insecurity, the underdeveloped economy, their limited military capabilities and marginalized international position in the second half of the 19th century were immensely more influential to their colonial policies as shall be seen. It also means that these two countries were nowhere near on being on par with Germany, France or Britain. Instead they were closer at being "colonized", attacked or economically penetrated by them.

\section{Bibliography}

Afflerbach, Holger. "«Duo quum faciunt idem...» Militärische Aspekte der deutschen und italienischen Kolonialgeschichte vor dem Ersten Weltkrieg" In Annali dell'Istituto Storico Italo-Germanico, 24. Trento, 1998, 115-146.

Black, Cyril. The Modernization of Japan and Russia: A Comparative Study (Perspectives on modernization). New York: Free Press, 1975.

38. Similarly, the Meiji Restoration was a typical "revolution from the above" brought about and shaped in their favour, according to their theories, by elements of the upper classes (court members, samurai of any rank). In contrast the Italian unification process (1848-1871) was based on popular support for emancipation and liberal ideals as formulated by Giuseppe Mazzini and despite the central role of Piedmont's dynasty and army, the unification was solidified by a series of local referenda. In late 19th century Germany and Japan, the oligarchic leadership backed or utilized monarchical authority and prestige, retarded democratization and strengthened its position. See Eiko Ikegami, "Citizenship and National Identity in Early Meiji Japan, 1868-1889: A Comparative Assessment" in International Review of Social History, 40, noS3 (1995), 218-219. 
Boltho, Andrea. "Italy and the World Economy, 1861-2011." In Italy, Germany, Japan: From Economic Miracles to Virtual Stagnation, International Conference, Rome, 12-15 October 2011.

Conrad, Sebastian. German colonialism, a short history. Cambridge: Cambridge University. Press, 2012.

Converin, Robert. "The Germans in Africa before 1918." In Colonialism in Africa, 1870-1960, edited by L. H. Gann, P. Duignan, vol. 1, The History and Politics of Colonialism, 1870-1914, London, 1969.

Cross, Sherrie. "Prestige and Comfort: The development of Social Darwinism in early Meiji Japan, and the role of Edward Sylvester Morse." In Annals of Science, 53, no. 4(1996).

Fletcher, Roger. "Revisionism and Wilhelmine Imperialism." Journal of Contemporary History, 23, no. 3(1988): 347-366.

Forbes Ian L. D. "Social Imperialism and Wilhelmine German." The Historical Journal, 22, n. 2(Jun., 1979): 334-335.

Gann, L. H., Duignan Peter. The rulers of German Africa, 1884-1914. Stanford, 1997.

Ghisalberti, Carlo. "Due colonialismi a confronto: Italia e Germania nella loro espansione oltremare sino alla prima guerra mondiale." Clio Rivista Trimestrale di Studi Storici, 33, no. 2(1997): 327-344.

Grimmer-Solem, Erik. "German Social Science, Meiji Conservatism, and the Peculiarities of Japanese History." Journal of World History, 16, no. 2(2005).

Henderson, William Otto. Studies in German colonial history. London, 1962.

Henderson, William Otto. The German colonial empire. London: Frank Cass, 1993.

Hirakawa, Sukehiro. Japan's Love-Hate Relationship with the West. Folkestone, 2005.

Ikegami, Eiko. "Citizenship and National Identity in Early Meiji Japan, 1868-1889: A Comparative Assessment." In International Review of Social History, 40, no S3(1995): 185-221.

Lowe, John. The Great Powers and the German Problem (1865-1925). London: Routledge, 1994.

Martin, Bernd. Japan and Germany in the Modern World. Oxford: Berghahn Books, 1995.

Mazzei, Franco. "La Risposta Del Giappone Alla Sfida Modernizzante dell' Occidente." In 1868 Italia-Giappone: Intrecci Culturali, edited by Rosa Caroli. Venice, 2008.

Mommsen, Wolfgang J. "Bismarck, the Concert of Europe, and the Future of West Africa, 1883-1885." In Bismarck, Europe and Africa. The Berlin Conference 1884-1885 and the onset of Partition, edited by Stig Forster, Wolfgang J. Mommsen and Ronald Robinson). New York, 1988.

Oermann, Nils Ole. Mission, Church and State Relations in South West Africa under German Rule (1884-1915). Stuttgart: Franz Steiner Verlag, 1999.

Perras, Arne. Carl Peters and German Imperialism 1856-1918 A Political Biography. New York: Clarendon Press of Oxford University Press, 2004.

Pierson, John D. "The Early Liberal Thought of Tokutomi Sohō. Some Problems of Western Social Theory in Meiji Japan." In Monumenta Nipponica, 29, no. 2(1974).

Samsonovic, Arkadij Erusalimskij. Bismarck: Diplomazia e Militarismo. Rome, 1969.

Smith Woodruff, D. "The Ideology of German Colonialism, 1840-1906." The Journal of Modern History, 46, no. 4 (1974): 641-643.

Smith, Woodruff D. German Colonial Empire. Ann Arbor, 1998. 
Steinmetz, George. The devil's handwriting. Precoloniality and the German colonial state in Qingdao, Samoa and Southwest Africa. Chicago 2007.

van der Heyden, Ulrich. "Christian Missionary Societies in the German Colonies, 1884/851914/15." In German Colonialism, Race, the Holocaust, and Postwar Germany, edited by V. Langbehn, M. Salama. New York, 2011.

von Strandmann, Hatmut Pogge. "The Purpose of German Colonialism, or the Long Shadow of Bismarck's Colonial Policy." In German Colonialism, Race, the Holocaust, and Postwar Germany, edited by V. Langbehn, M. Salama. New York, 2011.

Wippich, Rolf-Harald. "Infected with German Measles: Meiji Japan Under German Cultural Influence." In History of European Ideas, 20, no. 1-3(1995). 
